\title{
Connotation and Practice of People-oriented Idea in the Ideological and Political Education in Colleges and Universities
}

\author{
Yongkun $\mathrm{Yu}$ \\ Jilin Agricultural University, Changchun 130118, China
}

\begin{abstract}
The traditional ideological and political education, in the aspect of education goal and the education content, especially in the education method existence malpractice, often ignores the individual differences of students, and hinder the development of students' independent thinking and personalized thinking. This article discusses the method of ideological and political education for College students under the "people-oriented" perspective, uses the effective methods and means strive to make these methods have practicability and maneuverability in real education. The core part of this paper is, taking Southwest Petroleum University as an example, questionnaire is carried out based on College students' daily ideological and political education content carried out, and analyzes the achievements and shortcomings. On the basis of current college students' ideological and political education method incommensurate to the people-oriented concept survey analysis, according to the people-oriented theory and the related theory of the ideological and political education, ideological and political education method innovation and people-oriented concept are integrated into a unified researching system, so as to explore the relationship between them and put forward specific measures. In order to solve the problems find in the questionnaire, it is necessary to take the classroom teaching as a platform, strengthen ideological and political education of college students to by taking the construction of campus network as a platform, create a whole atmosphere of moral education, construct campus culture platform combined with psychological health education, take social practice activities as a platform to achieve effective dispersal, and expand the space for students to display themselves.
\end{abstract}

Keywords: people-oriented; ideological and political education; method research.

\section{Introduction}

With more and more "the generation after 90s" entering the University, "the generation after 90s" has become the main body of College students. As college students in a specific time and space, they have their own unique characteristics in either ideological and moral cognition or behaviors from the perspective of both physical development and psychological development. They are open-minded, good at performance, and creative that they have been no longer satisfied with the rigid acceptance of some specific things. On the contrary, they prefer to capture new ideas and new trends. Therefore, for carrying out ideological and political education under the background of this new era, it is required to fully consider the characteristics of their thinking and behavior characteristics, adhere to the people-oriented idea. Only by doing this can the ideological and political education closely combine with the practical thinking and behavior of college students, promote them positively shape themselves, and eventually become the social subject who have excellent personality characteristics and good quality. Based on lots of literature review, taking Southwest Petroleum University as an example, this paper uses the method of questionnaire to investigate College students' ideological and political education of the college students and analyze the achievements and shortcomings. On the basis of current college students' ideological and political education method incommensurate to the people-oriented concept survey analysis, according to the people-oriented theory and the related theory of the ideological and political education, ideological and political education method innovation and people-oriented concept are integrated into a unified researching system, so as to explore the relationship between them, analyze the theoretical point of these two problems. In the meanwhile, considering the reality that ideological and political education faced with challenges, this 
paper summarizes and gropes effective method to improve ideological and political education in the guidance of people-oriented concept.

\section{Current Situation and Analysis of College Students' Ideological and Political Education Methods from the Perspective of "people oriented" Idea}

\subsection{Design and Implementation of the survey}

A questionnaire survey was conducted on the students, and the forms of interviews were conducted with some ideological and political courses teachers. A questionnaire survey was conducted among students at different levels of four different grades in Southwest Petroleum University. The survey questionnaires were issued 2000 in total, and recycled 1930, so the recovery rate is $96 \%$. Among them, the male students are 1230 , with a proportion of $63.8 \%$ in the total. The number of girls involved in the survey is 700 , with a proportion of $36.2 \%$. The liberal arts major occupies $26.4 \%$, science major occupies $35.3 \%$, and engineering major occupies $38.3 \%$. The content of the survey is the content of ideological and moral status of college students and the evaluation of ideological and political education methods. It refers to three outlooks of college students, world outlook, life outlook, value outlook, and three moralities, social morality, professional ethics, and family virtues. It also includes the evaluation of college students of the concrete form of ideological and political education and evaluation of the current state of themselves. From the perspective of people-oriented" idea to understand the current situation of College students' ideological and political education method and existing problems, combine with the investigation analysis to proceed field research, and summarize inductive method of ideological and political education of College students under the guidance of the concept of "people-oriented" to adapt to the times.

\subsection{Analysis of Survey Result}

Research mainly includes two parts, the investigation of current status of the ideological and moral of College students and survey of evaluation of college students on the ideological and political education. First of all, in the investigation of College students' ideological and moral status, when being asked the understanding of communism, there are 1200 people, namely $60 \%$ believing that it is possible to be realized; about 400 people, namely $22 \%$ holding that it is bound to be realized; about 340 people, namely $18 \%$ thinking that it is just a dream, as shown in figure 1 . When being asked about the value orientation that students approved, there are 840 students, namely $45 \%$ believing that the most approved value orientation is possessing lofty character; about 530 people, namely $25 \%$ thinking that it is contributing a lot to society; about 300 people, namely $16 \%$ holding that it is having their own enterprise; about 200 people, namely 9\% thinking it is living comfortably; about 60 people, namely $3 \%$ believing it is possessing lots of money; about 80 people, $4 \%$ choosing other, as shown in figure 2 .

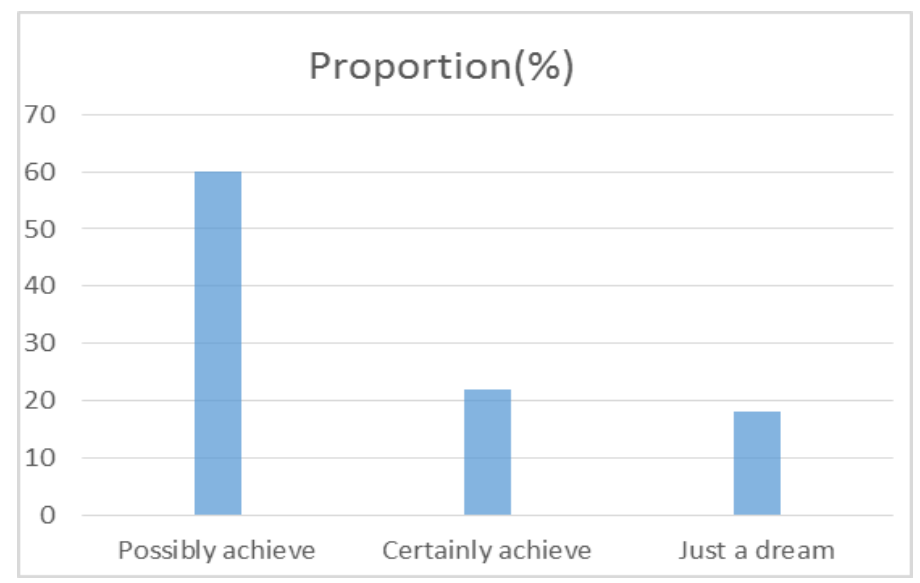

Figure 1 Understanding of Communism 


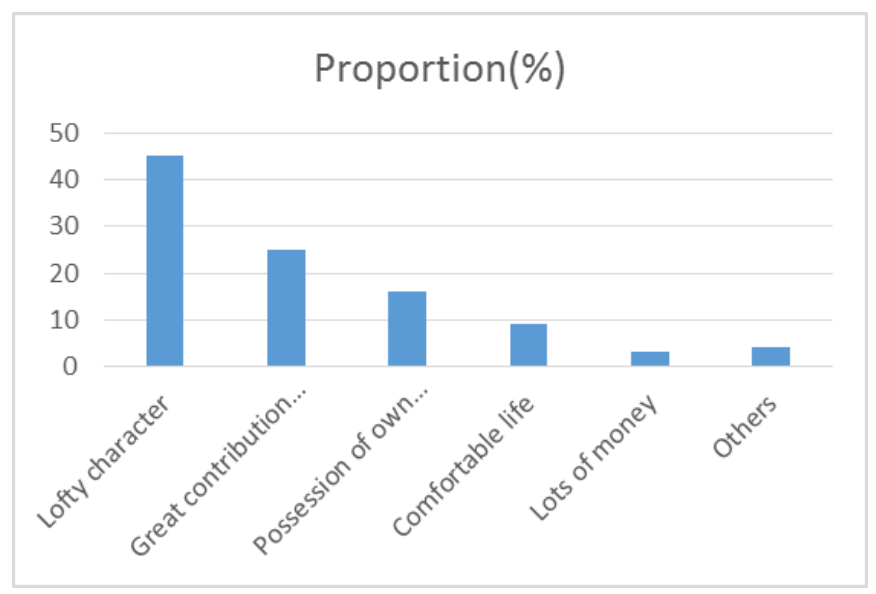

Figure 2 Value Orientation Approved by Students

The data in the survey results show that currently most of the students have strong political awareness and the majority of them are positive in political. They are concerned with trend of motherland's development and social hot issues. In a word, they hold a positive attitude towards Chinese political situation.

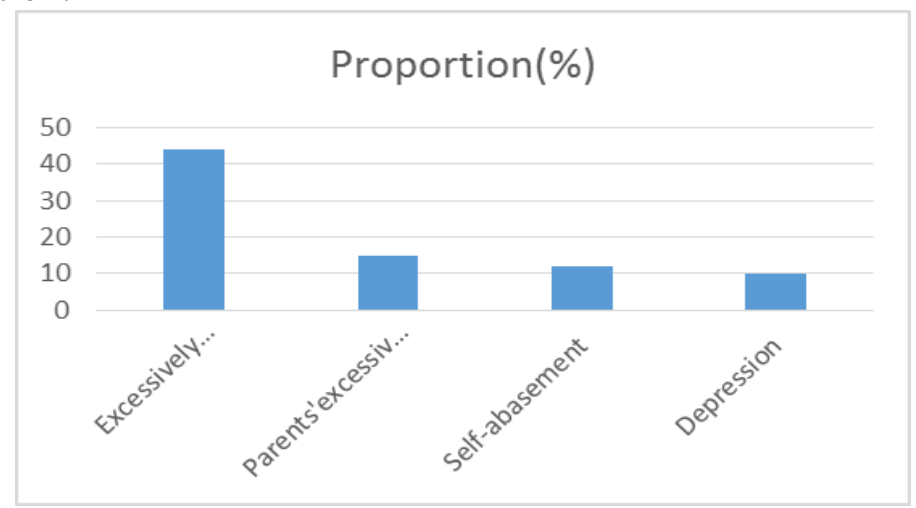

Figure 3 the Biggest Mental Pressure of College Students

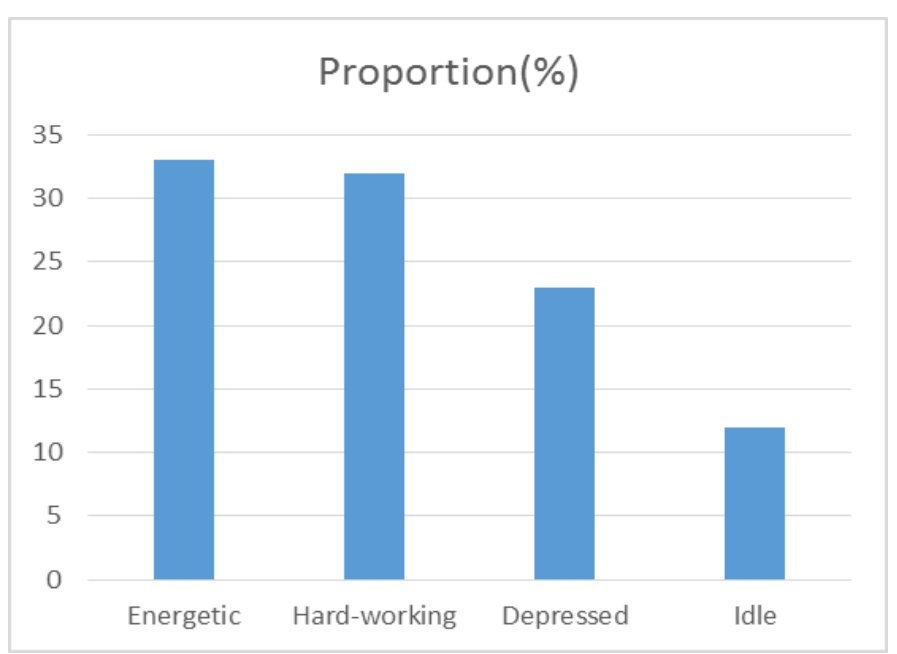

Figure 4 Evaluation of Current College Life

In the investigation of evaluation of College students on their current state, when talking about their mental burden, there are 800 students, $44 \%$ are excessively worried about their prospect; about 320 students, $15 \%$ thinking it is caused by parents' excessive expectation; about160 students, $12 \%$ believing it is due to self-abasement; about 300, 10\% thinking it is resulted by depression, as shown in figure 3. As for evaluation of current College life, there are 630 students, $33 \%$ holding that it is comfortable and energetic; about 600 students, $32 \%$ are studying hard so as to establish the foundation for the future; about 400, 23\% are worried about their future; about 200 students, $12 \%$ having nothing to do, as shown in figure 4. 
Data from the survey results show that the majority of the students are healthy in the physical and mental development, but ability to cope with emergencies is weak. In the questionnaire survey of high school students, students are very concerned about the employment problem. In the interview, the majority of students are optimistic about their career choice, but some students still have psychological problems. In the current college campus, it is an important task for our ideological and political education of strengthening teachers' and students' psychological health counseling, and paying attention to the way and strengthen the effect.

\section{Implementation Method of Ideological and Political Education of College Students from the Perspective of "People-oriented" Idea}

From the point of view of the results of the survey, the common problem remained to be solved for Colleges and universities is the development of ideological and political education. The healthy mechanism of promoting the development of College students' ideological and political education has not been fully established. To solve the practical problems in the ideological and political education of College students, it needs not only to put the ideological and political education of College students into the connotation of "people-oriented" concept to consider, but also requires to take the "people-oriented" philosophy as the fundamental guiding principle of College students' ideological and political education, consciously include college students' ideological and political education into the overall planning for economic and social development, the reform and development of colleges and universities, construction of academic and professional construction, and let it become one of the important parts, so as to promote mutually to establish long-term harmonious developing mechanism.

\subsection{Strengthening the Ideological and Political Education of College Students Based on Classroom Teaching}

(1)Attach Importance to Learning Instead of Teaching

In the process of teaching, the aim of teaching is to make the students accept the knowledge, and the process is process of method guidance, in which the intention is to initiate and learning is the key. Therefore, in the teaching process, it is supposed to take playing students initiative as the main task, and indoctrination as the sub-task. It should also be highlighted in the examination. That is to say, do not set a question that may cause cheating in the test. Try to avoid the cheating in the exam from the questions. As for the subject, it is set freely so that students can play self-creative as much as possible. Reduce the burden of students to memorize. In the meanwhile, provides students with full imagination and creation space to apply their knowledge to solve the problems encountered in reality.

(2)Combine Theoretical teaching with Reality

Ideological and political theory course teaching should pay attention to the combination with real life. It can start from the introduction of vivid examples to lead to the basic concepts and theories, and then from the case analysis process to sum up the basic method. For example, "ideological and moral cultivation and legal basis" should pay more attention to the cases and organize discussions. Examination can try pumping interview questions, which can avoid plagiarism phenomenon and improve the students' oral expression ability and speak impromptu. If the classroom atmosphere is more active, the number of discussions can be appropriately increased. In order to attract students' attention, various forms of debate, speech and multimedia teaching can be applied, which is beneficial to cultivate students' comprehensive quality.

\subsection{Strengthening the Ideological and Political Education of College Students Based on the Construction of the Campus Network}

Network information occupies an important position in the information resources of university personnel training, and it is the forward position of the development of "network society" in China. Network information flow menacing, the environment of ideological and political education is no longer closed. In the research on network ideological and political education, scholars sum up that the current college students' network application is mainly concentrated in information acquisition, communication, games entertainment, and electronic commerce these four aspects. This analysis is 
beneficial for helping us to combine the law of the ideological and political education to find the starting point.

(1) Guide Self-learning

Contemporary college students are characterized by behavior-fashionable, open-minded and personality-distinctive who are a group of modern people with curiosity, suspicion and creativity. Compared with the traditional educated people, firstly, they are active rather than passive in educational activities. In the network, instead of passively receive information, they actively search for information, select information, and accept the information. Secondly, in the educational activities, they often play subjectivity role in education. They like to exchange information, release information, and try to influence other audiences. In modern society, students' learning space and time concept are greatly changed. Network teaching is not only a challenge to the traditional teaching mode, but also the need of the information age. Providing independent and personalized learning is the basic concept of higher education in the 21st century. There are network classroom, excellent course, learning theory, scientific research and so on, providing the documents about ideological and political theory courses and multimedia data for students so that it is possible to realize student's autonomous learning.

(2)Develop Quality and Promote Communication

Information network technology has not only expanded the space and channel of the ideological and political education of College students, but also puts forward a series of challenges. In the new era, the ideological and political education should be innovative, and strengthen and improve the ideological and political education of college students. The network has become a new carrier of ideological and political education, which makes the ideological and political education more flexible and efficient. In the concrete operation, it is no longer the traditional instillation, but equal dialogue on a platform, and the model has become the "educators-the intermediary-the educated". Due to the particularity of online communication, it is possible to use anonymity to make easy and free communication. It can relate to what the student's really cared about. In addition, the school can use network news server to give positive guidance of world outlook values, and make use of electronic bulletin system electronic notice to proceed theme forum. Moreover, through communication and interaction, discover the ideological trend of the education object; using multimedia technology of network propagation to make lectures, teaching and counseling so as to make the network ideological and political education more advantageous.

\subsection{Expand Students' Self Display Space with Social Practice as a Platform}

(1) Carry out Social Practice Education Based on Academic Research

Under the guidance of professional knowledge, the contemporary university student's academic practice organizes students to participate in social activities or Colleges students spontaneously utilize professional knowledge to understand and service for the society of all operational activities and actions. It intends to cultivate and train the comprehensive ability of College students, improve their comprehensive quality, and enhance their sense of social responsibility. Colleges and universities, through encouraging students to participate in extracurricular science and technology competition of "Challenge Cup", "Mathematical Modeling Contest", and "Mechanical Design Competition" and so on, cultivate students awareness of advocating science, pursuing knowledge, and innovating, to meet the challenges.

(2) Carry out Social Practice Education Guided by Social Activities

Social activities is the beautiful scenery in university campus, which melts the thought, scientific property and interesting character as one. Rich and colorful college students' social activities attract their wide participation, and in the coating process, deepen the understanding of their own potential, which is conducive to the cultivation of students' autonomy and collectivism spirit. To improve the interesting character and participation of ideological and political education is of great significance to carry out ideological and political education of college students. Through real practice experience, combine ideological and political education with carrying out of activities, enable students participate 
in practice, at the same time, they are baptized by thought, which improves their ideological and moral qualities and achieves the goal of ideological and political work.

\section{Conclusion}

To explore the ideological and political education of college students in the perspective of "people oriented" idea becomes the inevitable trend of ideological and political humanized education, which has a great significance in enhancing the effectiveness of ideological and political education of college students. From the perspective of people-oriented college students' ideological and political education method, taking Southwest University as an example to proceed research. Based on the research achievements at home and abroad, a comprehensive review is done for the current situation of ideological and political education in our country. It clearly confirm the significance of combining the methods of College ideological and political education research and people-oriented concept. Secondly, in view of practical problems of current methods of ideological and political education incommensurate to the concept of "people-oriented" idea, design questionnaire investigation. According to the survey results, combine with the analysis of new characteristics of contemporary College students, seek methods of achieving the combination of ideological and political education and people-centered philosophy. Finally, combined with the specific situation of the method of the ideological and political education, on the basis of absorption of many outstanding scholars research results, the paper puts forward a series of flexible methods of ideological and political education, makes integrated use of a variety of ways to proceed the organic integration so as to promote a better ideological and political education.

\section{References}

[1] Yun Guo, Lin Bai. On the Effectiveness of Ideological and Political Education of Colleges and Universities from Methodology-From the Perspective of Ideological and Political Theory Courses [J]. Journal of Shanxi Datong University (Social Science Edition), 2016, 2: 020.

[2] Zhou Xiaoqiong. Ways of Integrating Media Literacy Education into Ideological and Political Education for College Students in the New Media Era [J]. International Journal for Innovation Education and Research, 2016, 3(6).

[3] Qin Xin. The Impact of Micro Media Communication on the Effectiveness of Ideological and Political Education and Its Countermeasures [J]. Higher Education of Social Science, 2016, 10(4).

[4] Xu Shasha. Research on Ideological and Political Education of Southwest Petroleum University Students in Micro Blog Era [J]. Creative Education, 2016, 7(02): 287.

[5] Fei Z H U. The Connotation and Practice of People-oriented in University Personnel Training [J]. 2016.

[6] Tao T. A.N.G. People oriented: the values of the people's livelihood of the communist party of China [J]. Journal of Changchun Institute of Technology (Social Sciences Edition), 2015, 2: 004.

[7] Gartzia Leire and Josune Baniandrés. Are people-oriented leaders perceived as less effective in task performance? Surprising results from two experimental studies [J]. Journal of Business Research, 2016, 69(2): 508-516.

[8] Collins Alan. Building a people-oriented security community the ASEAN way [M]. Routledge, 2013. 